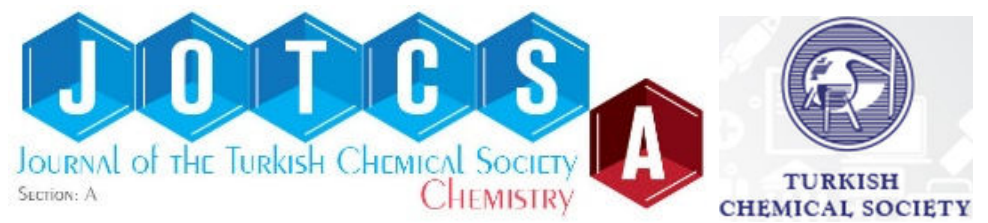

(This article was presented to the 28th National Chemistry Congress and submitted to JOTCSA as a full manuscript)

\title{
Thermal, Mechanical and Water Resistance Properties of LDPE/Starch Bio-Based Polymer Blends for Food Packing Applications
}

\author{
Hale Berber Yamak ${ }^{1, *}$ \\ ${ }^{1}$ Yildiz Technical University, Department of Metallurgical and Materials Engineering, 34220, \\ Istanbul, Turkey
}

\begin{abstract}
In this study, low density polyethylene (LDPE) was melt-blended with starch using twin screw extruder to form biodegradable polymer blends. The LDPE/starch blend films used in food packing were obtained by hot pressing of the granules produced by extrusion process. The starch content was varied from 0 to $40 \mathrm{wt} \%$ of LDPE. To provide fine starch dispersion, glycerol and zinc stearate were used as plasticizer and compatibilizer, respectively. The effect of starch content on the properties of LDPE film was investigated. A good dispersion was achieved for low starch contents (10 and $20 \mathrm{wt} \%$ ), but agglomeration of the starch particles occurred in the presence of high amounts of starch (>20 wt\%). The addition of starch to LDPE reduced the tensile strength, elongation at break, crystallinity, and water resistance of LDPE. This decline in the LDPE properties was dramatic when the starch content was increased to 30 $w t \%$ in the blend. In addition, silver nanoparticles as antibacterial agent were incorporated to the biodegradable LDPE blends where LDPE/starch weight ratio of 60/40. The effects of these nanoparticles on morphological, mechanical, thermal and water resistance properties of the LDPE/starch biodegradable blends were investigated. It was observed that the incorporation of nanoparticles to the LDPE/starch blend was completely changed the morphology of the film, and accordingly, the mechanical, thermal, and water resistance properties were varied depending on the silver nanoparticle content in LDPE/starch blend film. Moreover, antibacterial activities of the nanocomposite films against gram-negative bacteria ( $E$. coli) and grampositive bacteria ( $S$. aureus) were determined by measuring the inhibition zone around each film. However, the nanocomposite films did not show any antibacterial activities in the presence of silver nanoparticles as an antibacterial agent.
\end{abstract}

Keywords: Biodegradable materials; low density polyethylene; starch; food packing.

Submitted: July 04, 2016. Revised: October 09, 2016. Accepted: October 31, 2016.

Cite this: Berber Yamak H. Thermal, Mechanical and Water Resistance Properties of LDPE/Starch Bio-Based Polymer Blends for Food Packing Applications. JOTCSA. $2016 ; 3(3): 637-58$.

DOI: To be assigned.

*Corresponding author. E-mail: hberber@yildiz.edu.tr. 


\section{INTRODUCTION}

The use of plastics as a packaging material has continuously increased worldwide due to their excellent physicochemical, mechanical and barrier properties, ease of processing, lightweight nature, low cost, and versatility. More than $40 \%$ of the plastics are used for packaging and almost half of them are used for food packaging in the form of films, sheets, bottles, cups, tubs, and trays, etc. [1, 2]. However, these petroleum-based plastics are not biodegradable and totally recyclable, and cause serious environmental and economic problems related to the increasing volume of plastic waste and the consumption of non-renewable resources arising from plastic production [1-3]. For these reasons, there has been an increasing interest for making and use of environmentally friendly biodegradable food packing material instead of synthetic polymers [4,5]. Although biopolymers obtained from renewable natural resources such as cellulose, starch, chitosan, and proteins are preferred for the preparation of biodegradable packaging materials $[1,4-7]$, their weak mechanical properties and poor barrier properties have strongly limited the use of these polymers for food packing applications [2, 8, 9]. In addition, they are not convenient for industrial processes via extrusion, melt mixing or other thermal processes because of their difficult processes. They are not thermoplastic materials and can be degraded before melting $[1,8]$. Therefore, manufacturing a product using $100 \%$ renewable resources seems impossible in the near future.

To obtain biodegradable polymers with desired properties, one of the most useful routes is blending of natural biopolymers with synthetic commercial polymers. The obtained biodegradable polymer can be decomposable and/or compostable when there is a sufficient amount of biopolymer in the blend, and also the microorganisms in waste disposal environment consume the biopolymer $[3,10]$. Here, the biopolymer is not only consumed but also the degradation rate of the synthetic polymer increases as a result of the enhancing of chain oxidation reactions [8]. Thus, the use of these biodegradable blends in daily life can reduce the volume of plastic waste and the use of petroleum-based plastic materials.

Among the petroleum-based plastics, low density polyethylene (LDPE) is the most extensively used packing material. Because of its hydrophobicity, high molecular weight, and absence of functional groups susceptible to microorganisms, it is hard to degrade under normal composting conditions, and the ever-increasing waste of this plastic constitutes a major environmental risk $[3,11]$. The melt blending of LDPE with a biopolymer such as starch makes it biodegradable $[3,12-15]$. Starch is a biopolymer derived from renewable resources such as corn, wheat, rice, and potato, and has a renovated interest to form biodegradable plastics due 
Berber Yamak, JOTCSA. 2016; 3(3): 637-656.

RESEARCH ARTICLE

to its lower price, wider availability, higher purity, non-toxicity, and very favorable environmental profile. It is composed of two types of molecules, linear amylose and branched amylopectin, and also has hydrophilic character and strong intermolecular hydrogen bonding, which cause its thermal decomposition temperature is lower than the melting temperature [4, 5]. Although, these properties make the starch unfavorable for use in the thermal processes of hydrophobic LDPE, it can possess thermoplastic character after some pretreatment involving gelatinization [15] and/or plasticization, which allow to disrupt the intermolecular hydrogen bonding and to progressively destroy the crystallinity $[16,17]$. The materials used to plasticize the starch such as glycerol, sorbitol, urea, and water not only allow the thermal processing, but also improve the compatibility of starch with LDPE, enhance the mechanical properties of the starch based blend films and the biodegradability rate [17-21]. However, the addition of such plasticizers could not sufficient to completely eliminate the weaknesses in dispersion, gloss, transparency, and mechanical properties such as tensile strength and tear strength, and gas barrier properties $[22,23]$. To overcome these problems caused by incompatibility in LDPE/starch blends, there have been various approaches including modification of starch such as stearic acid-grafted starch, adipate starch, acetylated starch and phthalate starch [24-26], the use of a compatibilizer, which have reactive groups such as maleic anhydride, maleate esters, glycidyl methacrylate and hydroxyl $[8,13,22,27]$ and the use of a crosslinking agent $[18,28]$.

In addition to the improvement of compatibility, physical appearance, and mechanical and barrier properties of the biodegradable food packing films, the incorporation of other additives into the films to enhance functional properties such as being antibacterial and antioxidant and the color is also extremely important for the quality of packing films and/or packed food. The antibacterial agents can make a longer shelf life and increase the food safety by delaying or preventing the growth of microorganisms on the food packing film surface [7]. Among these agents, silver nanoparticles (AgNPs) have strong antibacterial activity and broad-spectrum toxicity to microorganism as well as the unique catalytic, optic, and electronic properties, and thermal stability [29-32]. They can be incorporated into a wide range of packing materials from petroleum-based plastics such as polyethylene, polypropylene, polystyrene and nylon to biodegradable polymers such as chitosan, starch, and other synthetic biopolymers [33-35].

The object of this study was to produce the low density polyethylene (LDPE) based biodegradable films as food packing material. LDPE, used in blown film extrusion processes, was melt-blended with starch biopolymer. Glycerol and zinc stearate were used as plasticizer and compatibilizer, respectively to provide the fine dispersion of starch in LDPE matrix, and 
Berber Yamak, JOTCSA. 2016; 3(3): 637-656.

also AgNPs were used as an antibacterial agent for gaining antibacterial properties to the LDPE/starch biodegradable blends. The structure of LDPE/starch blends was studied by FTIR. The effects of starch and AgNPs contents on the morphology, mechanical properties and crystallinity degree of the biodegradable films were investigated by SEM, mechanical test and DSC analyses. The water resistances of the films were analyzed by water absorption test and contact angle measurements. The antibacterial analyses of the AgNPs incorporated LDPE/starch blends were done by agar diffusion method. The antibacterial activities were evaluated whether the formation of clear zone around the samples as an indication of inhibition of the bacterial species.

\section{MATERIALS AND METHODS}

\section{Chemicals}

Film-grade low density polyethylene pellets (LDPE; Petilen F2-12), with a density of 0.920 $\mathrm{g} / \mathrm{cm}^{3}$ and a melt flow index (MFI) of $2.0 \mathrm{~g} / 10 \mathrm{~min}\left(190{ }^{\circ} \mathrm{C} / 2.16 \mathrm{~kg}\right.$; ASTM D1238), was supplied by PETKIM Petrochemical Co., Turkey. The soluble potato starch and pure glycerol ( $87 \%$ purity) were purchased from Merck, Turkey. Zinc stearate used as compatibilizer was a product of Melos Co., Turkey. Silver nanoparticles (AgNPs) within nano-sized zeolite, which were produced by ion exchange route, (AgZ; NKZFT89654) were used as antibacterial agent and supplied by Yıldız Kolor, Turkey. The weight ratio of silver to zeolite, Ag/zeolite was 1/2 and $\mathrm{Ag}$ average particle size was less than $20 \mathrm{~nm}$. All ingredients were used without further purification.

\section{Preparation of LDPE/Starch Blend Films}

Starch was dried in an air-circulating oven at $100{ }^{\circ} \mathrm{C}$ for $2 \mathrm{~h}$. Just prior to the extrusion process, starch and glycerol in a constant weight ratio of 70:30 were manually mixed. The mixture in polyethylene bag was left overnight under atmospheric conditions to allow the starch granules to swell. Then, the milled LDPE and zinc stearate were added to this bag and the whole was again mixed thoroughly. To prepare the LDPE/starch blends, the mixture was fed into a co-rotating twin screw extruder with a screw diameter of $22 \mathrm{~mm}$ and an L/D ratio of 40 (Coperion Company, China). The barrel temperature profile along the extruder was in a range of $70-180{ }^{\circ} \mathrm{C}$ (from feed zone to die), and the screw speed was kept constant at 250 rpm while the material feed rate was $18 \mathrm{rpm}$. The starch contents in the blends were varied from 0 to $40 \mathrm{wt} \%$ (relative to LDPE), and also zinc stearate was used at a constant amount of 3 wt\% based on the total polymer consisting of LDPE and starch for all samples. The chemical 
structures of components used in the preparation of LDPE/starch blends were given in Scheme 1. After the extrusion process, the films were formed from the LDPE/starch blend samples obtained as granules. Firstly, the neat LDPE granules and the blend samples were melted using two-roll mills (LabTech Engineering Co. Inc., Thailand) at $140{ }^{\circ} \mathrm{C}$ and $35 \mathrm{rpm}$ rotate speed, and then 4 grams of melted samples were hot-pressed at $140{ }^{\circ} \mathrm{C}$ under $16 \mathrm{MPa}$ for $15 \mathrm{~s}$ into plates using LabTech hydraulic laboratory press. The thickness of films was $250 \mu \mathrm{m}$.

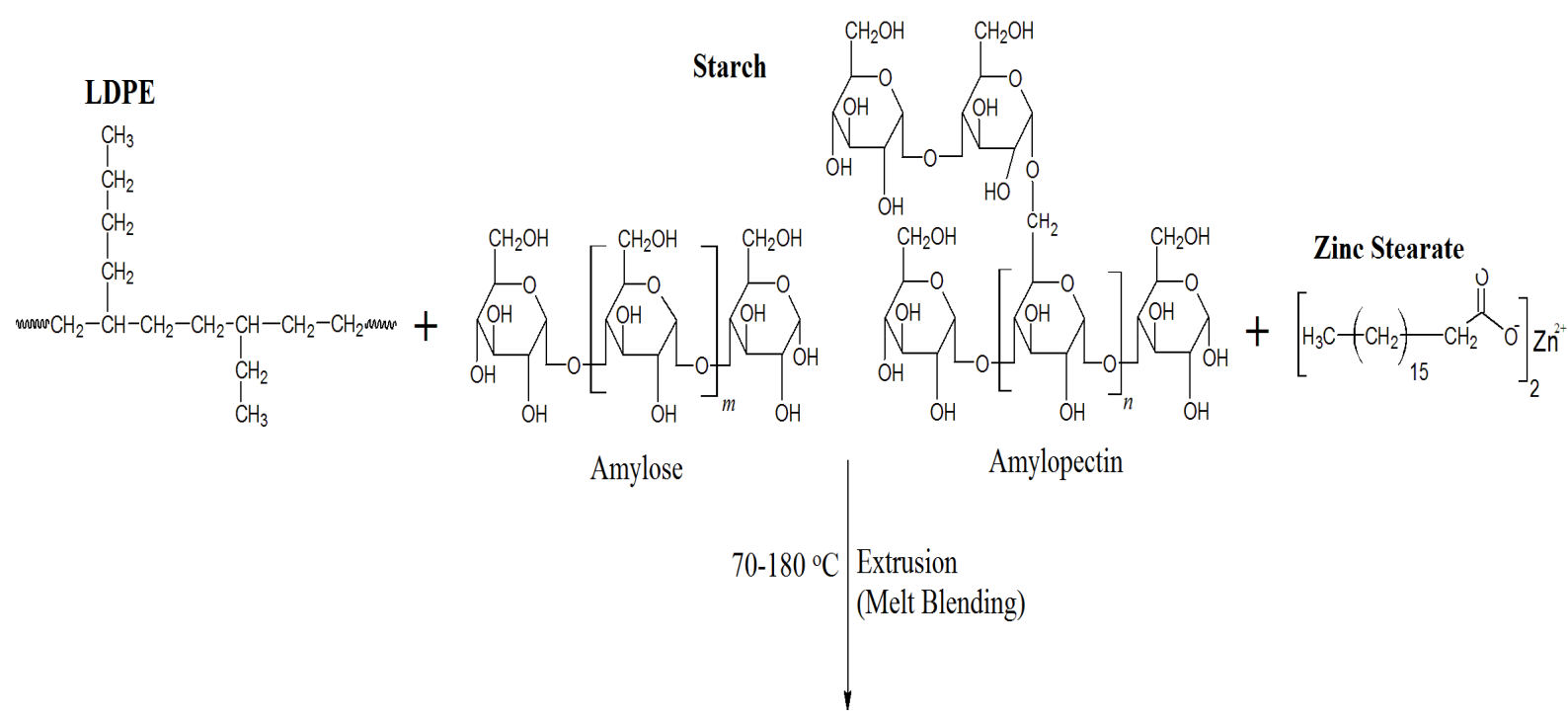

Biodegredable LDPE/Starch Polymer Blends

Scheme 1. Preparation of LDPE/starch blends.

\section{Preparation of LDPE/Starch-AgNPs Nanocomposite Films}

The starch was plasticized with glycerol in a constant weight ratio of 70:30. Then, the silver nanoparticles, AgNPs within nano-sized zeolite were melt-blended with the mixture consisting of pure milled LDPE, plasticized starch, and zinc stearate by using a co-rotating twin screw extruder. The concentrations of silver nanoparticles in total polymer matrix formed by LDPE and starch were ranged from $100 \mathrm{ppm}$ to $300 \mathrm{ppm}$ while the weight ratio of LDPE to starch, LDPE/starch was kept constant at $60 / 40$ for all the nanocomposites. After the extrusion processes, the nanocomposite films with the thickness of $250 \mu \mathrm{m}$ were formed from the obtained granules. To produce the nanocomposite films, the same process conditions were applied from beginning to end as those applied for LDPE/starch blend samples, as described in detail above.

\section{Characterization Methods}

FTIR analyses of the blends were carried out by using IR-Prestige 21 FTIR Spectrometer (Shimadzu, Japan) in ATR (Attenuated Total Reflection) mode. The wavenumber range, scan number for per sample and wave resolution were $4000-750 \mathrm{~cm}^{-1}, 16$ and $4 \mathrm{~cm}^{-1}$, respectively. 
Berber Yamak, JOTCSA. 2016; 3(3): 637-656.

RESEARCH ARTICLE

Scanning Electron Microscopy, SEM (Zeiss EVO® LS 10) was used to investigate the surface morphology of the film samples which were coated with thin carbon film before the analyses. Mechanical properties were analyzed using a Devotrans tensile testing machine (model GPG; No. 161072 CKS; Devotrans, Turkey) equipped with a $10 \mathrm{kN}$ load cell. The test cross speed was $100 \mathrm{~mm} / \mathrm{min}$. The results were obtained from an average of three tests for each sample. Differential Scanning Calorimetry (DSC) analyses of the films were done using a Perkin Elmer Pyris 6 type DSC under $\mathrm{N}_{2}$ atmosphere. The samples weighted 5-7 mg were heated from 25 to $200{ }^{\circ} \mathrm{C}$ at a heating rate of $10^{\circ} \mathrm{C} / \mathrm{min}$ and kept isothermally at $200^{\circ} \mathrm{C}$ for $1 \mathrm{~min}$. Then, they were cooled down to $25^{\circ} \mathrm{C}$ and reheated to $200{ }^{\circ} \mathrm{C}$ at a rate of $10{ }^{\circ} \mathrm{C} / \mathrm{min}$. Melting and crystallization data of the samples were obtained from second heating and first cooling scans, respectively. The antibacterial activity of the silver nanoparticles incorporated LDPE/starch films was tested by agar diffusion method. Escherichia coli (Gram negative) and Staphylococcus aureus (Gram positive) were used as two common bacterial pathogens. They were grown in Petri dishes with agar as the culture medium, and then disc-shaped film samples were placed on the surface and incubated at for $24 \mathrm{~h}$ at $37{ }^{\circ} \mathrm{C}$. The antibacterial activity results were examined by the formation of clear zone around the samples as an indication of inhibition of the bacterial species. The surface wettability of the films was investigated by measuring the contact angle of water drop with $5 \mu \mathrm{L}$ volume on the film surface using a KSV Instruments Cam 200 contact angle meter at room temperature. The final contact angle value for each sample was obtained from an average of five measurements. Water absorption test of the films were performed according to gravimetric methods. Before testing, the film samples were dried in an air circulating oven at $80^{\circ} \mathrm{C}$ for 24 hours and then their initial weights $\left(\mathrm{w}_{\mathrm{i}}\right)$ were recorded. These dry samples were immersed in water and kept at ambient conditions until constant weight was reached. The final weights $\left(W_{f}\right)$ were recorded again, and the water absorption percentage of the samples ( $W_{a b}$ ) was calculated from the following equation:

$$
W_{a b}=\frac{W_{f}-W_{i}}{W_{i}} \times 100 \%
$$

\section{RESULTS AND DISCUSSION}

LDPE/starch blends in different weight ratios (100/0, 90/10, 80/20, 70/30 and 60/40) were prepared by a continuous single-step extrusion process using a co-rotating twin screw extruder. Starch was pretreated with glycerol for the plasticization before the process. To provide a fine dispersion of starch in LDPE matrix, zinc stearate was used as compatibilizer in the extrusion processes. The biodegradable films with homogenous appearance were obtained. Following this step, AgNPs within zeolite were incorporated to the LDPE/starch blend with weight ratio of $60 / 40$ by melt-blended method. The nanocomposite films with homogenous 
appearance were also obtained in three different AgNPs concentrations including 100, 200 and 300 ppm (relative to total polymer amount). Sample codes are given in Table 1.

Table 1. Sample codes of the LDPE/starch blends and the LDPE/starch-AgNP nanocomposites.

\begin{tabular}{lcc}
\hline Sample Code & $\begin{array}{c}\text { LDPE/Starch } \\
\text { (by weight) }\end{array}$ & $\begin{array}{c}\text { AgNPs* } \\
\text { (ppm) }\end{array}$ \\
\hline LDPE & $100 / 0$ & - \\
\hline $90 / 10$ & $90 / 10$ & - \\
\hline $80 / 20$ & $80 / 20$ & - \\
\hline $70 / 30$ & $70 / 30$ & - \\
\hline $60 / 40$ & $60 / 40$ & - \\
\hline $100 \mathrm{ppm}$ & $60 / 40$ & 100 \\
\hline $200 \mathrm{ppm}$ & $60 / 40$ & 200 \\
\hline $300 \mathrm{ppm}$ & $60 / 40$ & 300 \\
\hline
\end{tabular}

* Based on total polymer amount consisting of LDPE and starch.

\section{FTIR Analysis}

Figure 1 shows FTIR spectra of the pure LDPE and starch, and the obtained LDPE/starch blends with different starch contents. For the pure LDPE, the characteristic strong peaks at $2914 \mathrm{~cm}^{-1}$ and $2847 \mathrm{~cm}^{-1}$ correspond to asymmetric and symmetric $\mathrm{C}-\mathrm{H}$ stretching vibrations, respectively. The sharp peak at $1462 \mathrm{~cm}^{-1}$ and the double peaks at $729-719 \mathrm{~cm}^{-1}$ also indicate the $\mathrm{C}-\mathrm{H}$ bending and $\mathrm{C}-\mathrm{C}$ rocking deformation vibrations, respectively [36]. On the other hand, two broad and strong peaks at region of $3600-3000 \mathrm{~cm}^{-1}$ and $1050-950$ characterize the starch, and they are respectively attributed to $\mathrm{O}-\mathrm{H}$ and $\mathrm{C}-\mathrm{O}$ stretching vibrations, respectively. The weak broad band around $1640 \mathrm{~cm}^{-1}$ corresponds to $\mathrm{O}-\mathrm{H}$ bending. In the FTIR spectra of LDPE/starch blends, all characteristic peaks belonging to both LDPE and starch were observed. The intensities of the characteristic starch peaks were increased by increasing starch content in the blend. For the blends, the values of starch peaks were slightly shifted to left and also their peak width were narrower, compared with starch. These changes in the starch peaks indicates that there were new physical interactions between starch molecules and other components such as glycerol and zinc stearate instead of the intermolecular interactions between starch molecules. Moreover, the new peak appeared around $1740 \mathrm{~cm}^{-1}$, which is attributed to $\mathrm{C}=\mathrm{O}$ stretching vibration. This belongs to ester bond of the zinc stearate, showing the incorporation of zinc stearate to the blend structure. 


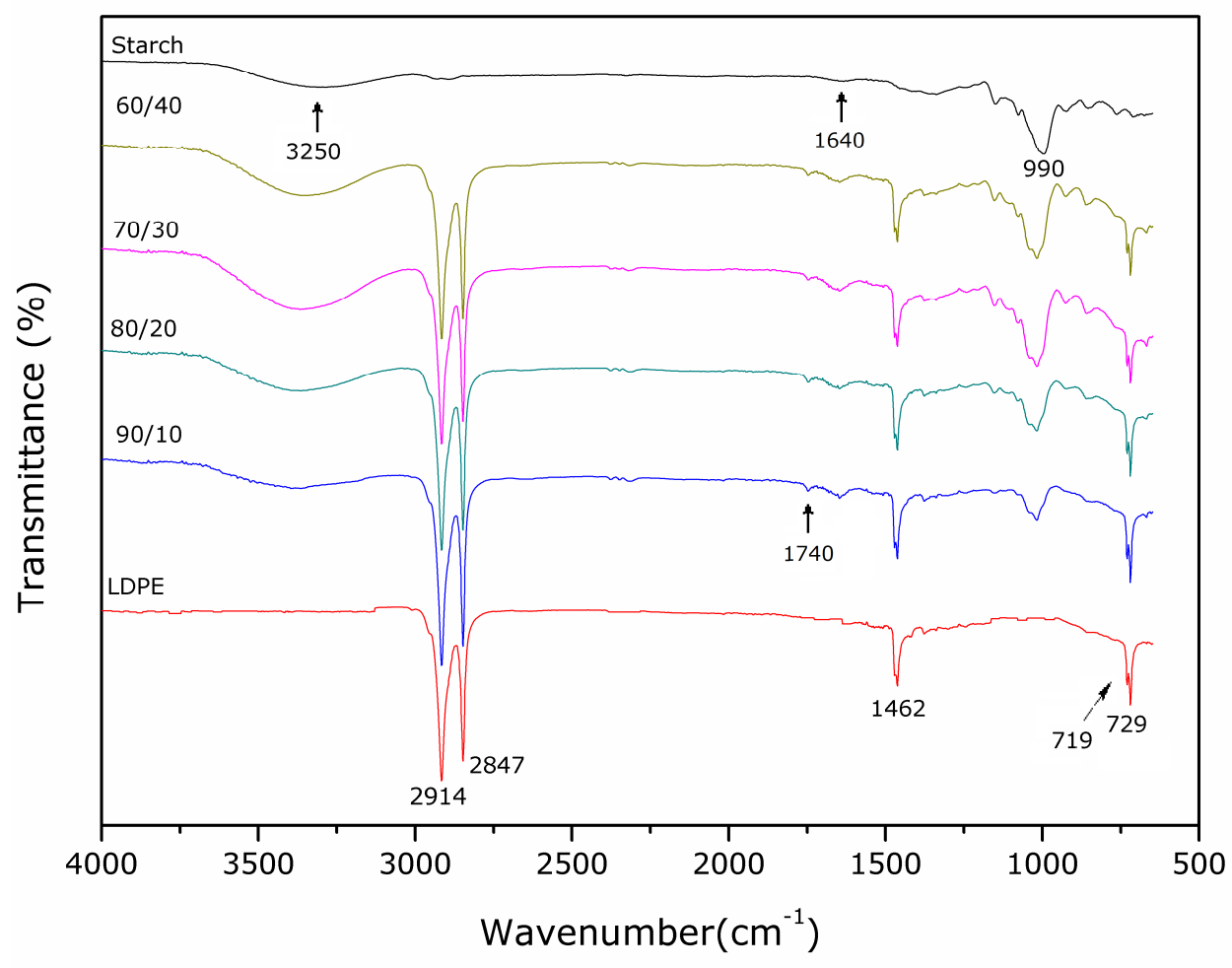

Figure 1. FTIR spectra of LDPE, starch and LDPE/starch blends.

\section{SEM Analysis}

The dispersion of starch in LDPE matrix was examined by SEM analysis. SEM micrographs of the pure LDPE and LDPE/starch blends with different starch content are given in Figure 2 (a-e). LDPE film had a smooth surface and showed a uniform continuous matrix. By the addition of starch particles into the LDPE matrix, the different surface morphologies were observed depending on the amount of starch. As seen in Figure 2(b) and (c), the LDPE/starch blends containing 10 and 20 wt\% starch exhibited a good dispersion of starch particles, any phase separation between LDPE and starch did not appear, and starch particles were embedded in the matrix. This indicated that the use of glycerol as a plasticizer and zinc stearate as a compatibilizer reduced the interfacial energy between the starch and LDPE phases and made them more compatible in these weight ratios [24].

However, the finer distribution of starch particles decreased with increasing starch content in the blends, and more a small amount of particle agglomeration was observed on the sample surface when the starch content was increased to $30 \mathrm{wt} \%$, as seen in Figure 2(d). The micrograph for the sample containing 40 wt\% starch, given in Figure 2(e) presented a rougher surface and separate larger agglomerated starch particles, and also few surface holes formed by removal of loosely embedded starch particles were detected, corresponding to 
incompatibility of starch and LDPE. This incompatibility can occur as a result of the weakened interfacial adhesion between LDPE and starch with increased hydrophilic starch content in hydrophobic LDPE, and also the decreased compatibilizing effect of zinc stearate for these two separate phases $[24,26,37]$.

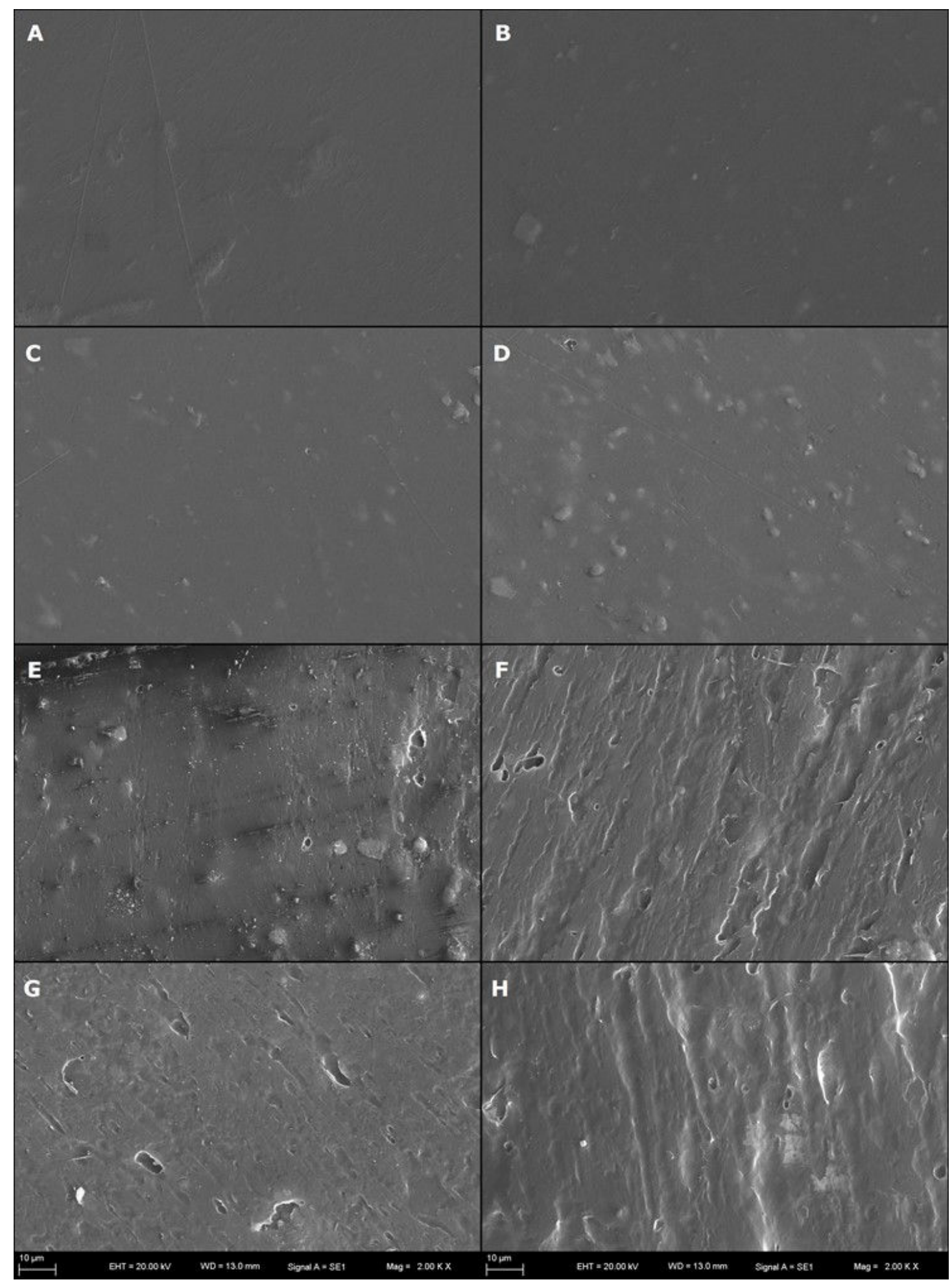

Figure 2. SEM micrographs of the pure LDPE (A), LDPE/starch blends; $90 / 10(B), 80 / 20(C)$, 70/30 (D) and 60/40 (D), and LDPE/starch-AgNP nanocomposites; $100 \mathrm{ppm}(\mathrm{F}), 200 \mathrm{ppm}(\mathrm{G})$ and $300 \mathrm{ppm}(\mathrm{H})$, (magnification of 2000x). 
Berber Yamak, JOTCSA. 2016; 3(3): 637-656.

In addition, AgNPs incorporating LDPE/starch nanocomposites showed a different surface morphology from the LDPE/starch blends, (Figure 2(f-h)). The nanocomposites were prepared by melt-mixing of silver nanoparticles within nano-sized zeolite and polymer matrix consisting of LDPE and starch in a constant weight ratio of 60/40. The amount of silver nanoparticles was varied from $100 \mathrm{ppm}$ to $300 \mathrm{ppm}$ (relative to the total polymer matrix). Although the agglomerated starch particles disappeared, the surface roughness, deep cracks and voids were observed, as seen Figure $2(\mathrm{f}-\mathrm{h})$. These images revealed that the AgNPs in zeolite prevented the agglomeration of starch particles in LDPE, compared to AgNPs-free LDPE/starch blend in Figure 2 (e). However, an extreme surface roughness, deep cracks and voids, which were appeared by the incorporation of AgNPs in zeolite as a third phase into the blend, indicate the formation of non-uniform and discontinuous structures, phase separations and inhomogeneous surfaces. Also, the surface voids and deep cracks were varied with increasing concentration of AgNPs in the nanocomposites.

\section{Mechanical Properties}

The tensile properties of pure LDPE, LDPE/starch blend and LDPE/starch-AgNP nanocomposite films are presented in Table 2. It was obviously seen that the tensile properties of LDPE were significantly affected by the presence of starch and its content, as expected. The results are agreement with other studies on LDPE/starch blends [37-40]. The tensile strength of LDPE was found to be $17.1 \mathrm{MPa}$ and decreased to 7.3 MPa with the increase of starch content to 40 wt\% in LDPE. The percentage elongation at break also decreased from 815\% (LDPE) to 640, 360, 36 and $24 \%$ when the weight ratio of starch in LDPE was increased to 10, 20, 30 and 40\%, respectively, and there was even a dramatic decrease over 30 wt\% of starch content, as seen in Table 2. These obtained results are consistent with the surface morphologies of the LDPE/starch blend films (Figure 2 (a-e)).

The mechanical properties of starch-based polymer blends are influenced by the dispersion of starch in the main polymer, because the dispersion primarily determines the microstructure of the blend [41]. By the incorporation of starch into the LDPE, a polar discontinuous phase forms in a nonpolar continuous phase of the LDPE [38]. If there are no interfacial strong interactions such as hydrogen bonds between these two phases having different polarities, the interfacial tension between the phases does not decrease sufficiently, so a weak interfacial adhesion and incompatibility occur, which lead to a mechanical rupture at the blend interface. This results in a decrease of the tensile strength and elongation at break, and an increase of fragility [25, 28, 37]. In addition, the significant drop in the elongation at break, which was observed for the samples with higher starch contents, could be due to the agglomeration of starch particles in 
Berber Yamak, JOTCSA. 2016; 3(3): 637-656.

RESEARCH ARTICLE

the blend. For the agglomerated large starch particles, particle-particle interactions are more dominant instead of particle-LDPE matrix interactions. This causes a greater phase separation, the poorer tensile properties, and especially the fractures at lower values of elongation [10, $26,37]$.

Table 2. The tensile properties of LDPE/starch blend and LDPE/starch-AgNP nanocomposite films.

\begin{tabular}{ccc}
\hline Sample & $\begin{array}{c}\text { Tensile Strength } \\
(\mathbf{m P a})\end{array}$ & $\begin{array}{c}\text { Elongation at Break } \\
\mathbf{( \% )}\end{array}$ \\
\hline LDPE & 17.1 & 813 \\
\hline $90 / 10$ & 12.8 & 640 \\
\hline $80 / 20$ & 8.3 & 360 \\
\hline $70 / 30$ & 7.5 & 36 \\
\hline $60 / 40$ & 7.3 & 24 \\
\hline $100 \mathrm{ppm}$ & 5.7 & 36 \\
\hline $200 \mathrm{ppm}$ & 5.5 & 22 \\
\hline $300 \mathrm{ppm}$ & 6.2 & 13 \\
\hline
\end{tabular}

On the other hand, the addition of AgNPs within zeolite to the LDPE/starch blend consisting of $60 / 40$ weight ratio showed variety in both mechanical properties depending on the nanoparticle concentration, as seen in Table 2. Although the agglomerated starch particles were not seen on SEM micrographs of the nanocomposite films, the obtained poor mechanical properties could be due to the intense roughness and presence of voids and cracks observed on the film surfaces, as seen in Figure $2(f-h)$. The incorporation of silver nanoparticles within nano-sized zeolite as a rigid third phase into the polymer blend has created the new filler-filler and/or filler-matrix interactions between LDPE matrix, starch particles and silver-doped zeolites, which prevents the formation of homogeneous and fine dispersed phases. This can explain the weaker mechanical properties of the obtained nanocomposite structures compared to the pure LDPE and LDPE/starch blends [37, 38].

\section{DSC Analysis}

Table 3 shows the DSC data including peak melting temperature $\left(T_{m}\right)$, peak crystallization temperature $\left(T_{c}\right)$, melting and crystallization enthalpies $\left(\Delta H_{m}\right.$ and $\left.\Delta H_{c}\right)$, and percent crystallinity $\left(X_{c}\right)$ of all resulting samples. Melting and crystallization curves obtained from second heating and first cooling cycles of the LDPE/starch blends and LDPE/starch-AgNP nanocomposites are given in Figure $3(a-b)$ and Figure $4(a-b)$, respectively. $X_{c}$ of LDPE phase was calculated using the following equation: 
Berber Yamak, JOTCSA. 2016; 3(3): 637-656.

$$
X_{c}=\left(\Delta H_{m}-\Delta H_{c}\right) / \Delta H_{m}^{o} \times 100
$$

where $\Delta H^{\circ} m$, the heat of melting for $100 \%$ crystalline PE was taken to be $293 \mathrm{~J} \mathrm{~g}^{-1}$ [42].

Table 3. DSC data of the pure LDPE, LDPE/starch blends and LDPE/starch-AgNP nanocomposites.

\begin{tabular}{cccccc}
\hline Sample & $\begin{array}{c}\mathbf{T}_{\mathbf{m}} \\
\left({ }^{\circ} \mathbf{C}\right)\end{array}$ & $\begin{array}{c}\mathbf{T}_{\mathbf{c}} \\
\left({ }^{\circ} \mathbf{C}\right)\end{array}$ & $\begin{array}{c}\Delta \mathbf{H}_{\mathbf{m}} \\
(\mathbf{J} / \mathbf{g})\end{array}$ & $\begin{array}{c}\Delta \mathbf{H}_{\mathbf{c}} \\
(\mathbf{J} / \mathbf{g})\end{array}$ & $\begin{array}{c}\mathbf{X}_{\mathbf{c}} \\
(\mathbf{\%})\end{array}$ \\
\hline LDPE & 111.13 & 96.72 & 83.072 & -78.680 & 55.21 \\
\hline $80 / 10$ & 111.45 & 98.83 & 80.728 & -70.719 & 51.69 \\
\hline $70 / 20$ & 111.14 & 99.05 & 79.759 & -56.557 & 46.52 \\
\hline $60 / 40$ & 111.21 & 99.08 & 67.181 & -48.935 & 39.63 \\
\hline $100 \mathrm{ppm}$ & 111.37 & 99.08 & 65.404 & -45.255 & 37.77 \\
\hline $200 \mathrm{ppm}$ & 111.04 & 98.10 & 59.713 & -42.714 & 34.96 \\
\hline $300 \mathrm{ppm}$ & 110.35 & 98.11 & 57.302 & -36.988 & 32.18 \\
\hline
\end{tabular}

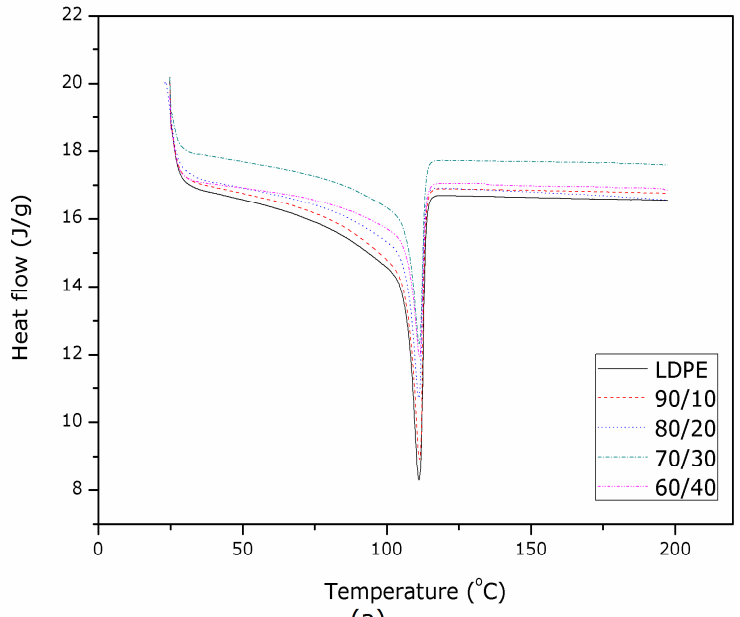

(a)

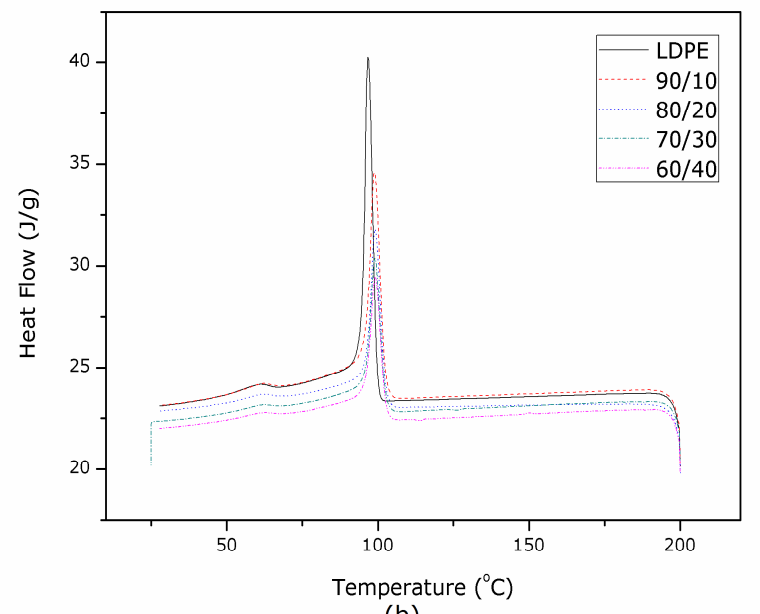

(b)

Figure 3. Melting (a) and crystallization (b) curves of LDPE/starch blends. 


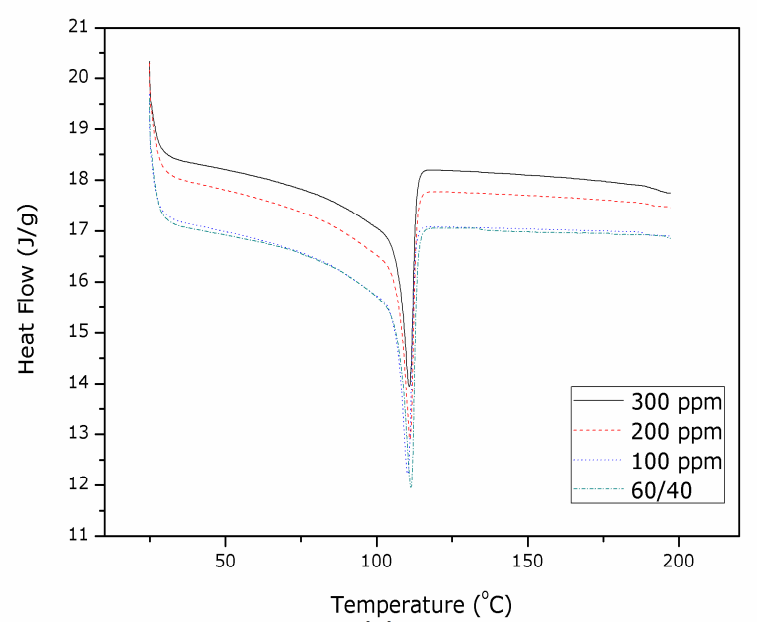

(a)

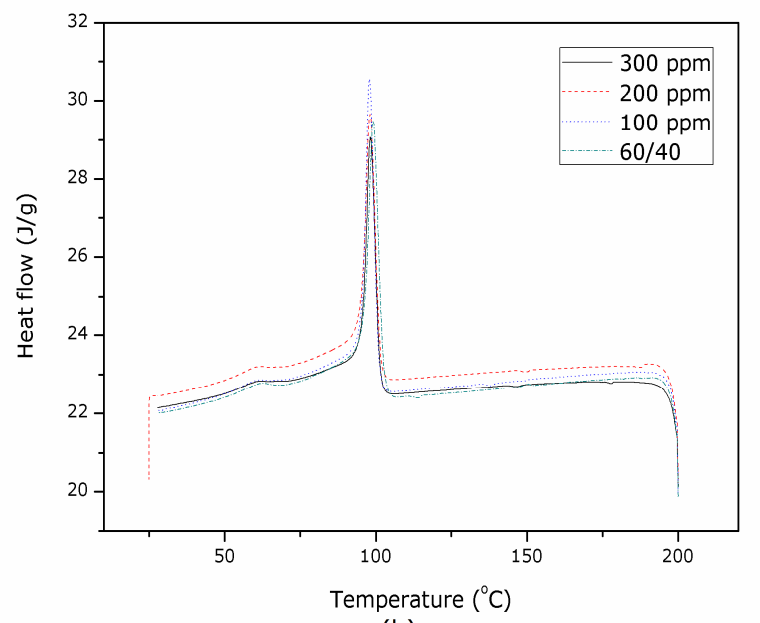

(b)

Figure 4. Melting (a) and crystallization (b) curves of LDPE/starch-AgNP nanocomposites.

The DSC curves of LDPE/starch blends and LDPE/starch-AgNP nanocomposites showed the same behavior with the pure LDPE. Any other endothermic peaks were not observed in the thermograms for these samples. These results indicate that there was no any degradation in the thermal properties of LDPE by the addition of starch and AgNPs, and the obtained films were compatible under these combinations [43]. There were also no significant differences between the $T_{m}$ of the LDPE/starch blends; their values were very close to that of LDPE. However, $T_{c}$ of the pure LDPE increased with the addition of starch, and this value was slightly shifted to higher values by increasing starch contents, as seen Figure 3 (b). The incorporation of AgNPs into the LDPE/starch blend with weight ratio of 60/40 caused a slight decrease in both temperatures, Figure 4 (a-b). In addition, the crystallinity degree decreased markedly with increasing content of starch in the blend, and also with the addition of AgNPs. This decrease was even in the blend appearing agglomeration. The \% crystallinity reduced up to $37.77 \%$ at $60 / 40$, LDPE/starch composition, and continued to fall up to $32.12 \%$ by the increasing amount of AgNPs to $300 \mathrm{ppm}$ in the LDPE/starch blend. This linear decrease with the increase in the amount of starch and AgNPs arises from the inhibition of close packing of the LDPE chains due to the incorporation of starch and AgNPs in the blends. Moreover, this result was attributed that glycerol and zinc stearate used as plasticizer and compatibilizer generated the interactions between starch and LDPE, and also between AgNPs within zeolite and these polymers during the extrusion process.

\section{Water Resistance Analyses}

Water resistances of the obtained films were investigated with two methods composed of contact angle and water absorption measurements. The measured water contact angle values 
Berber Yamak, JOTCSA. 2016; 3(3): 637-656.

including the right and left sides of the drop and the average contact angle of the films as a function of starch and AgNPs contents are given in Table 4. The images of water drops on these films are also given in Figure 5. The contact angle measurements give information about the degree of hydrophobicity/hydrophilicity of film surfaces. If the contact angle value of the water drop on the surface of a film sample is higher, it means that the film surface has a more hydrophobic character and is more resistant against water. This value is significantly influenced by the chemical composition of the film surface $[14,44]$. The average contact angle value was found to be $107.67^{\circ}$ for the pure LDPE film. Then, this value started to decrease by the addition of starch to the LDPE and fell to $91.53^{\circ}$ for the blend containing the highest amount of starch (as LDPE/starch=60/40). This phenomenon indicated that the addition of hydrophilic starch into the hydrophobic LDPE polymer matrix made significant changes in the physicochemical characteristics of film surfaces. As expected, hydrophilic character of the film surfaces increased with the increasing starch contents. On the other hand, a higher difference between the contact angle values of the right and left sides of the water drop was observed for the blends with high starch content. This difference is explained by the inhomogeneous surfaces formed due to the agglomeration of starch particles.

Table 4. The water contact angles and water absorption values of the obtained films.

\begin{tabular}{ccccc}
\hline Sample & $\begin{array}{c}\mathbf{Q}_{\mathbf{L}} \\
\left({ }^{\circ}\right)\end{array}$ & $\begin{array}{c}\mathbf{Q}_{\mathbf{R}} \\
\left({ }^{\circ}\right)\end{array}$ & $\begin{array}{c}\mathbf{Q}_{\text {average }} \\
(\mathbf{(})\end{array}$ & $\begin{array}{c}\mathbf{W}_{\mathbf{a b}} \\
(\mathbf{\%})\end{array}$ \\
\hline LDPE & 107.72 & 107.62 & 107.67 & 0.00 \\
\hline $90 / 10$ & 101.08 & 101.63 & 96.53 & 2.75 \\
\hline $80 / 20$ & 94.58 & 94.27 & 94.43 & 7.11 \\
\hline $70 / 30$ & 91.78 & 92.83 & 92.31 & 11.58 \\
\hline $60 / 40$ & 90.43 & 92.62 & 91.53 & 12.89 \\
\hline $100 \mathrm{ppm}$ & 95.93 & 97.97 & 96.95 & 12.71 \\
\hline $200 \mathrm{ppm}$ & 99.43 & 100.16 & 99.80 & 12.51 \\
\hline $300 \mathrm{ppm}$ & 101.20 & 104.14 & 102.67 & 12.08 \\
\hline
\end{tabular}

The incorporation of the AgNPs within zeolite to the LDPE/starch blend with weight ratio of $60 / 40$ completely changed the surface of the LDPE/starch film. The average contact angle values showed an increase with the presence of AgNPs in the polymer matrix. The value increased to $102.67^{\circ}$ when the AgNPs content rose to $300 \mathrm{ppm}$. These results indicate the formation of more hydrophobic LDPE-rich surfaces as a result of phase separation and nonuniform composite structure during extrusion. It was also detected big differences between the contact angle values of the right and left sides of the water drop, which was caused by the 
excessive surface roughness of these films. The contact angle measurements were consistent with the SEM analysis results.

The water absorption percentages of the films are given in Table 4. There was no water absorption for the pure LDPE, and then the absorption increased to $12.81 \%$ by the increasing ratio of hydrophilic starch to $40 \mathrm{wt} \%$ in the hydrophobic LDPE polymer. The incorporation of the AgNPs into the LDPE/starch blend made no significant changes in the water absorption percentages of the nanocomposites.
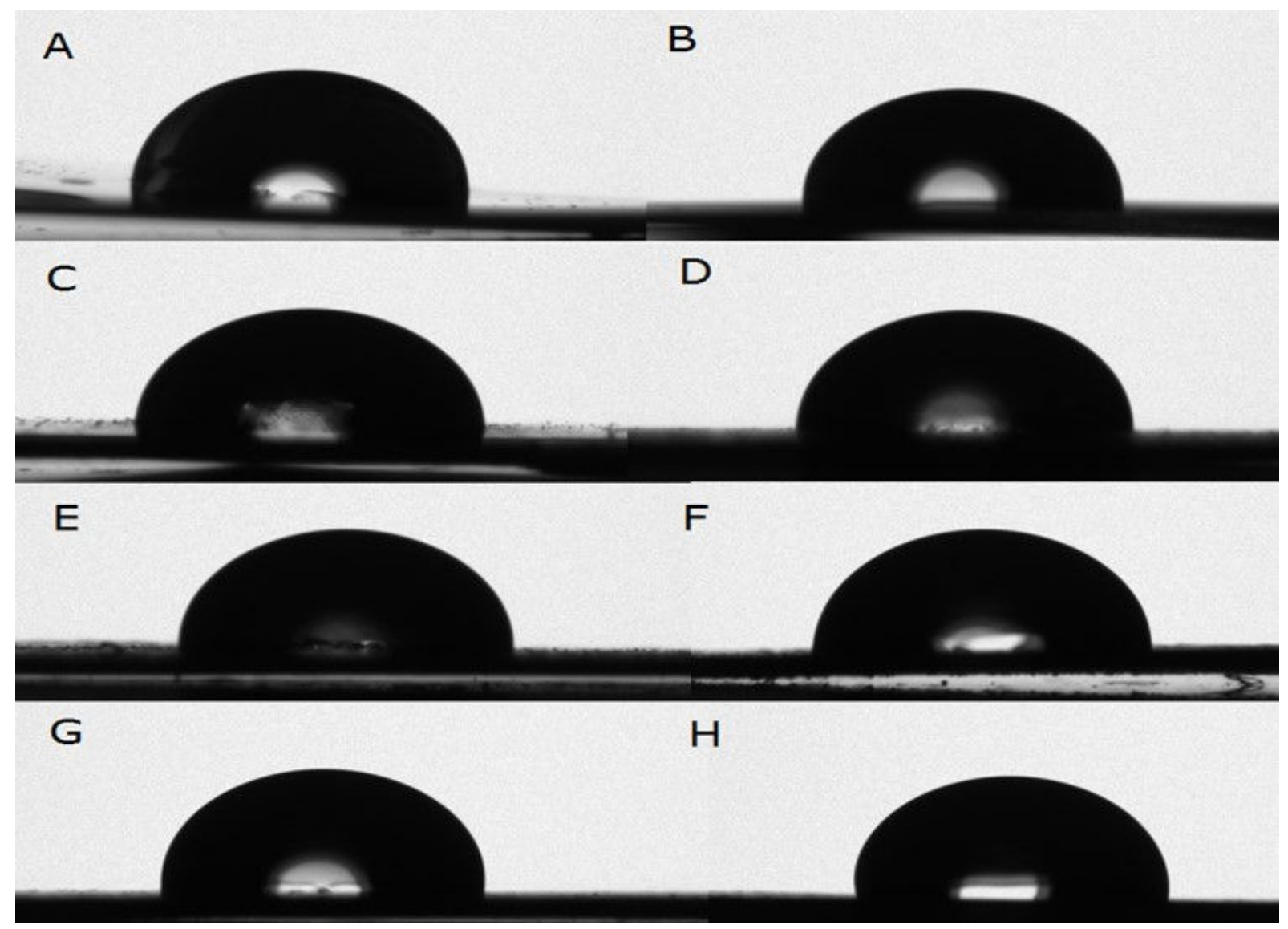

Figure 5. The images of water drops on the pure LDPE (A), LDPE/starch blend; 90/10(B), 80/20(C), 70/30 (D) and 60/40 (D), and LDPE/starch-AgNP nanocomposites; 100 ppm(F), 200 $\mathrm{ppm}(\mathrm{G})$ and $300 \mathrm{ppm}(\mathrm{H})$ films.

\section{Antibacterial Activity}

The AgNPs within zeolite were incorporated to the LDPE/starch biodegradable polymer blends by extrusion method. The antibacterial activities of the obtained films with AgNPs were investigated by agar diffusion method. Figure 6 shows the AgNPs incorporated nanocomposite 
films in the Petri dishes containing grown bacterial species, Escherichia coli (Gram negative) and Staphylococcus aureus (Gram positive). The formation of any clear zone around the samples, as an indication of inhibition of the bacterial species, was not osbserved. This zone forms when the diffusion of antibacterial agent in agar occurs. As seen in Figure 6, the creation of no clear zone in all samples consisting of AgNPs as antibacterial agent indicated that any diffusion of AgNPS from the sample to the agar medium with bacterial species did not occur. This may have arisen as a result of the chemical composition of the polymer mixture and/or the applying methods for the production of nanocomposites and their films.

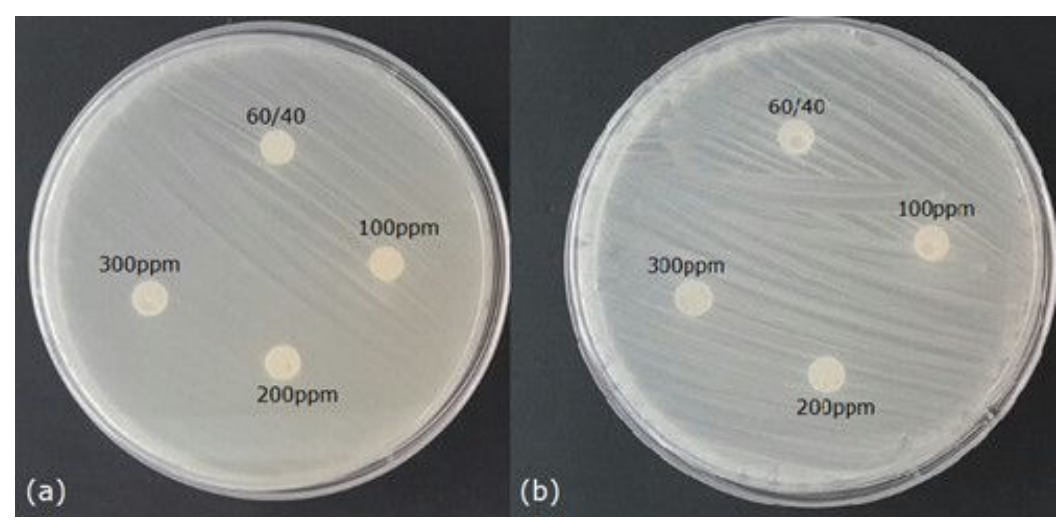

Figure 6. Appearance of AgNPs incorporated LDPE/starch nanocomposite films against $E$. coli (a) and S. aureus (b).

\section{CONCLUSION}

The biodegradable polymer blends were produced by melt blending of synthetic LDPE and the starch biopolymer for the food packing applications. The effects of starch content on the film properties were investigated in detail. The compatible films were obtained for low starch concentrations while the agglomerations of the starch particles in the blend occurred for higher concentrations of starch. The tensile properties and crystallinity degree of the LDPE decreased with the increasing content of starch in the blend. The water resistance of the hydrophobic LDPE was dropped by the addition of starch to this polymer. The incorporation of AgNPs within zeolite used as antibacterial agent caused the phase separation in the nanocomposite and the obtaining an inhomogeneous and discontinuous composite structure. The tensile properties and crystallinity decreased by this incorporation. In addition, it was not observed any antibacterial activities in these nanocomposite films where AgNPs were used as an antibacterial agent. 


\section{REFERENCES}

1. Rhim J-W, Park H-M, Ha C-S. Bio-nanocomposites for food packaging applications. Prog Polym Sci. 2013;38:1629-52. DOI: 10.1016/j.progpolymsci.2013.05.008.

2. Siracusa V, Rocculi P, Romani S, Rosa MD. Biodegradable polymers for food packaging: a review. Trends Food Sci Tech. 2008;19:634-43. DOI: 10.1016/j.tifs.2008.07.003.

3. Shah AA, Hasan F, Hameed A, Ahmed S. Biological degradation of plastics: A comprehensive review. Biotechnol Adv. 2008;26:246-65. DOI: 10.1016/j.biotechadv.2007.12.005.

4. Halley PJ. 6 - Themoplastic starch biodegradable polymers A2 - Smith, Ray. Biodegradable Polymers for Industrial Applications. Woodhead Publishing; 2005. 140-62 p. ISBN: 978-1-85573-934-5.

5. Platt DK. Biodegredable Polymers Market Report: Rapra Technology; 2007. 11-7 p. ISBN: 185957-519-6.

6. Bastioli C. Handbook of Biodegradable Polymers Rapra Technology Limited; 2005. 257 p. ISBN: 1-85957-389-4.

7. Wihodo M, Moraru CI. Physical and chemical methods used to enhance the structure and mechanical properties of protein films: A review. J Food Eng. 2013;114:292-302. DOI:

10.1016/j.jfoodeng.2012.08.021.

8. Inceoglu F, Menceloglu YZ. Transparent low-density polyethylene/starch nanocomposite films. J Appl Polym Sci. 2013;129:1907-14. DOI: 10.1002/app.38811.

9. Guilbert S, Cuq B, Gontard N. Recent innovations in edible and/or biodegradable packaging materials. Food Addit Contam Part A-Chem. 1997;14:741-51. DOI: 10.1080/02652039709374585.

10. Chandra R, Rustgi R. Biodegradable polymers. Prog Polym Sci. 1998;23:1273-335. DOI: 10.1016/S0079-6700(97)00039-7.

11. Chiellini E, Corti A, Swift G. Biodegradation of thermally-oxidized, fragmented low-density polyethylenes. Polym Degrad Stab. 2003;81:341-51. DOI: 10.1016/s0141-3910(03)00105-8.

12. Pedroso AG, Rosa DS. Mechanical, thermal and morphological characterization of recycled LDPE/corn starch blends. Carbohydr Polym. 2005;59:1-9. DOI: 10.1016/j.carbpol.2004.08.018.

13. Pedroso AG, Rosa DS. Effects of the compatibilizer PE-g-GMA on the mechanical, thermal and morphological properties of virgin and reprocessed LDPE/corn starch blends. Polym Adv Technol. 2005;16:310-7. DOI: 10.1002/pat.581.

14. Peres AM, Pires RR, Orefice RL. Evaluation of the effect of reprocessing on the structure and properties of low density polyethylene/thermoplastic starch blends. Carbohydr Polym. 2016;136:210-5. DOI: $10.1016 /$ j.carbpol.2015.09.047.

15. Psomiadou E, Arvanitoyannis I, Biliaderis CG, Ogawa H, Kawasaki N. Biodegradable films made from low density polyethylene (LDPE), wheat starch and soluble starch for food packaging applications. Part 2. Carbohydr Polym. 1997;33:227-42. DOI: 10.1016/S0144-8617(97)00032-5.

16. Róz ALD, Carvalho AJF, Gandini A, Curvelo AAS. The effect of plasticizers on thermoplastic starch compositions obtained by melt processing. Carbohydr Polym. 2006;63:417-24. DOI: 10.1016/j.carbpol.2005.09.017.

17. Griffin GJL. Environmentally Degradable PolymersStarch polymer blends. Polym Degrad Stab. 1994;45:241-7. DOI: 10.1016/0141-3910(94)90141-4.

18. Garg S, Jana AK. Studies on the properties and characteristics of starch-LDPE blend films using cross-linked, glycerol modified, cross-linked and glycerol modified starch. Eur Polym J. 2007;43:3976-87. DOI: $10.1016 /$ j.eurpolymj.2007.06.030. 
Berber Yamak, JOTCSA. 2016; 3(3): 637-656.

19. Wang YJ, Liu W, Sun Z. Effects of glycerol and PE-g-MA on morphology, thermal and tensile properties of LDPE and rice starch blends. J Appl Polym Sci. 2004;92:344-50. DOI: 10.1002/app.20015.

20. Yang JH, Yu JG, Ma XF. Study on the properties of ethylenebisformamide and sorbitol plasticized corn starch (ESPTPS). Carbohydr Polym. 2006;66:110-6. DOI: 10.1016/j.carbpol.2006.02.029.

21. Ma XF, Yu JG, Wan JJ. Urea and ethanolamine as a mixed plasticizer for thermoplastic starch. Carbohydr Polym. 2006;64:267-73. DOI: 10.1016/j.carbpol.2005.11.042.

22. Sabetzadeh M, Bagheri R, Masoomi M. Effect of corn starch content in thermoplastic starch/lowdensity polyethylene blends on their mechanical and flow properties. J Appl Polym Sci. 2012;126:E63-E9. DOI: $10.1002 / a p p .36329$.

23. Fabra MJ, López-Rubio A, Ambrosio-Martín J, Lagaron JM. Improving the barrier properties of thermoplastic corn starch-based films containing bacterial cellulose nanowhiskers by means of PHA electrospun coatings of interest in food packaging. Food Hydrocolloids. 2016;61:261-8. DOI: 10.1016/j.foodhyd.2016.05.025.

24. Khanoonkon N, Yoksan R, Ogale AA. Morphological characteristics of stearic acid-grafted starchcompatibilized linear low density polyethylene/thermoplastic starch blown film. Eur Polym J. 2016;76:266-77. DOI: 10.1016/j.eurpolymj.2016.02.001.

25. Nakamura EM, Cordi L, Almeida GSG, Duran N, Mei LHI. Study and development of LDPE/starch partially biodegradable compounds. J Mater Process Technol. 2005;162-163:236-41. DOI: 10.1016/j.jmatprotec.2005.02.007.

26. Thakore IM, Desai S, Sarawade BD, Devi S. Studies on biodegradability, morphology and thermomechanical properties of LDPE/modified starch blends. Eur Polym J. 2001;37:151-60. DOI: 10.1016/S0014-3057(00)00086-0.

27. Girija BG, Sailaja RRN. Low-density polyethylene/plasticized tapioca starch blends with the lowdensity polyethylene functionalized with maleate ester: Mechanical and thermal properties. J Appl Polym Sci. 2006;101:1109-20. DOI: 10.1002/app.24025.

28. Hoque ME, Ye TJ, Yong LC, Mohd Dahlan K. Sago Starch-Mixed Low-Density Polyethylene Biodegradable Polymer: Synthesis and Characterization. Journal of Materials. 2013;2013:7. DOI: $10.1155 / 2013 / 365380$.

29. Carlson C, Hussain SM, Schrand AM, K. Braydich-Stolle L, Hess KL, Jones RL, et al. Unique Cellular Interaction of Silver Nanoparticles: Size-Dependent Generation of Reactive Oxygen Species. The Journal of Physical Chemistry B. 2008;112:13608-19. DOI: 10.1021/jp712087m.

30. Dallas P, Sharma VK, Zboril R. Silver polymeric nanocomposites as advanced antimicrobial agents: Classification, synthetic paths, applications, and perspectives. Adv Colloid Interface Sci. 2011;166:119-35. DOI: 10.1016/j.cis.2011.05.008.

31. Russell AD, Hugo WB. 7 Antimicrobial Activity and Action of Silver. Ellis GP, Luscombe DK, editors. Progress in Medicinal Chemistry. Elsevier; 1994. 351-70 p. ISBN: 0079-6468.

32. Azeredo HMCd. Nanocomposites for food packaging applications. Food Res Int. 2009;42:1240-53. DOI: $10.1016 /$ j.foodres.2009.03.019.

33. Cheviron $P$, Gouanvé F, Espuche E. Effect of silver nanoparticles' generation routes on the morphology, oxygen, and water transport properties of starch nanocomposite films. J Nanopart Res. 2015;17:1-16. DOI: 10.1007/s11051-015-3173-4.

34. Jokar M, Rahman RA, Ibrahim NA, Abdullah LC, Tan CP. Melt Production and Antimicrobial Efficiency of Low-Density Polyethylene (LDPE)-Silver Nanocomposite Film. Food Bioprocess Technol. 2012;5:719-28. DOI: 10.1007/s11947-010-0329-1.

35. Appendini $\mathrm{P}$, Hotchkiss $\mathrm{JH}$. Review of antimicrobial food packaging. Innov Food Sci Emerg. 2002;3:113-26. DOI: 10.1016/S1466-8564(02)00012-7.

36. Alkan U, Kilic M, Karabul Y, Yamak HB, Okutan M, Icelli O. Electrical and Mechanical Properties of LDPE/PANI Composites. J Nanoelectron Optoelectron. 2016;11:343-8. DOI: 10.1166/jno.2016.1889. 
37. Beg MDH, Kormin S, Bijarimi M, Zaman HU. Preparation and Characterization of Low-Density Polyethylene/Thermoplastic Starch Composites. Adv Polym Tech. 2016;35:n/a-n/a. DOI: 10.1002/adv.21521.

38. Oromiehie AR, Lari TT, Rabiee A. Physical and thermal mechanical properties of corn starch/LDPE composites. J Appl Polym Sci. 2013;127:1128-34. DOI: 10.1002/app.37877.

39. Gupta AP, Sharma M, Kumar V. Preparation and characterization of potato starch based low density polyethylene/low density polyethylene grafted maleic anhydride biodegradable polymer composite. Polym-Plast Technol Eng. 2008;47:953-9. DOI: 10.1080/03602550802274597.

40. Gupta AP, Sharma M. Characterization of Biodegradable Packaging Films Derived from Potato Starch and LDPE Grafted with Maleic Anhydride-LDPE Composition. Part-II. J Polym Environ. 2010;18:492-9. DOI: 10.1007/s10924-010-0214-z.

41. Wang H, Zeng CC, Elkovitch M, Lee LJ, Koelling KW. Processing and properties of polymeric nanocomposites. Polym Eng Sci. 2001;41:2036-46. DOI: 10.1002/pen.10899.

42. Wunderlich B, Czornyj G. A Study of Equilibrium Melting of Polyethylene. Macromolecules. 1977;10:906-13. DOI: 10.1021/ma60059a006.

43. Gupta AP, Kumar V, Sharma M. Formulation and Characterization of Biodegradable Packaging Film Derived from Potato Starch \& LDPE Grafted with Maleic Anhydride-LDPE Composition. J Polym Environ. 2010;18:484-91. DOI: 10.1007/s10924-010-0213-0.

44. Yamak HB, Yildirim H. Improvement of film properties of vinyl acetate based emulsion polymers by using different types of maleic acid diesters. Prog Org Coat. 2013;76:1874-8. DOI:

10.1016/j.porgcoat.2013.05.032. 
Türkçe Öz ve Anahtar Kelimeler

\section{Gıda Ambalaj Uygulamaları İçin LDPE/Nişasta Biyo-Polimer Karışımlarının Isıl, Mekanik ve Su Direnç Özellikleri}

Öz: Bu çalışmada, biyo-bozunur polimer karışımları oluşturmak için; düşük yoğunluklu polietilen (LDPE) nişasta ile çift vidalı ekstruder kullanarak eriyik halinde harmanlandı. Gıda ambalajlamada kullanılan LDPE/nişasta karışım filmleri, ekstrüzyon sürecinde üretilen granüllerin sıcak preslenmesiyle elde edildi. Karışımlardaki nişasta içeriği, LDPE'nin ağırlıkça \%0-40'ı olacak şekilde değiştitirildi. Karışım içerisinde iyi bir nişasta dağılımı sağlamak için; gliserol ve çinko stearat sırası ile plastikleştirici ve uyumlaştırıcı olarak kullanıldı. LDPE filminin özellikleri üzerine nişasta içeriğinin etkisi incelendi. Düşük nişasta içeriklerinde (ağırlıkça \%10 ve 20) iyi bir dağılım elde edildi, ancak daha yüksek içeriklerde (\%20'den büyük) nişasta taneciklerinin topaklanması meydana geldi. Nişastanın LDPE'ye ilave edilmesi; LDPE'nin gerilme mukavemetini, kopmadaki uzamasını, kristallilik derecesini ve suya karşı direncini düşürdü. LDPE'nin özelliklerindeki bu düşme, nişasta içeriği \%30'a artırıldığında ise dramatik bir şekilde gözlendi. Buna ek olarak, antibakteriyel katkı maddesi olarak gümüş nanotanecikleri LDPE/nişasta ağırlıkça oranının 60/40 olarak sabit tutulduğu biyo-bozunur LDPE karışımlarına ilave edildi. Bu nanotaneciklerin LDPE/nişasta biyo-bozunur karışımlarının morfolojik, mekanik, ısıl ve su direnci özellikleri üzerine etkisi incelendi. LDPE/nişasta karışımlarına nanotaneciklerin ilavesinin LDPE/nişasta filminin morfolojisini tamamen değiştirdiği gözlendi ve LDPE/nişasta karışım filminin mekanik, ısıl ve su direnci özellikleri, içindeki gümüş nanotaneciklerinin miktarına bağı olarak değişti. Ayrıca, nanokompozit filmlerin gram negatif (E. coli) ve gram pozitif (S. aureus) bakterilerine karşı antibakteriyel aktiviteleri her film etrafındaki inhibisyon bölgesinin ölçülmesiyle belirlendi. Ancak, nanokompozit filmler antibakteriyel katkı maddesi olarak gümüş nanotanecikleri içermesine rağmen hiç bir antibakteriyel aktivite göstermedi.

Anahtar kelimeler: Biyo-bozunur malzemeler; düşük yoğunluklu polietilen; nişasta; gıda ambalajı.

Gönderme: 04 Temmuz 2016. Düzeltme: 09 Ekim 2016. Kabul: 31 Ekim 2016. 